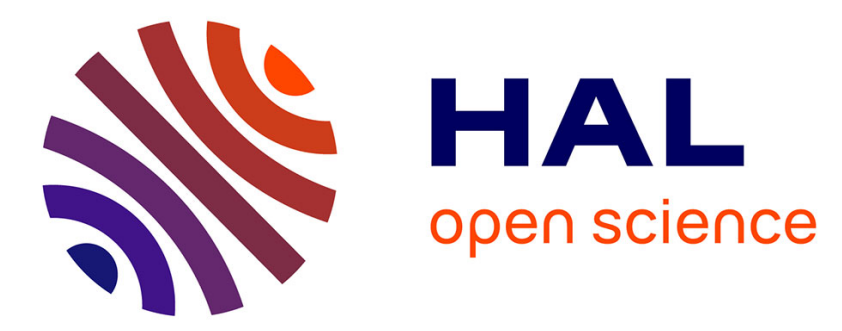

\title{
Actinopolyspora saharensis sp. nov., a novel halophilic actinomycete isolated from a Saharan soil of Algeria
} Atika Meklat, Noureddine Bouras, Abdelghani Zitouni, Florence Mathieu, Ahmed Lebrihi, Peter Schumann, Cathrin Spröer, Hans-Peter Klenk, Nasserdine Sabaou

\section{To cite this version:}

Atika Meklat, Noureddine Bouras, Abdelghani Zitouni, Florence Mathieu, Ahmed Lebrihi, et al.. Actinopolyspora saharensis sp. nov., a novel halophilic actinomycete isolated from a Saharan soil of Algeria. Antonie van Leeuwenhoek, 2013, vol. 103, pp. 771-776. 10.1007/s10482-012-9859-z . hal-00926526

\section{HAL Id: hal-00926526 https://hal.science/hal-00926526}

Submitted on 9 Jan 2014

HAL is a multi-disciplinary open access archive for the deposit and dissemination of scientific research documents, whether they are published or not. The documents may come from teaching and research institutions in France or abroad, or from public or private research centers.
L'archive ouverte pluridisciplinaire HAL, est destinée au dépôt et à la diffusion de documents scientifiques de niveau recherche, publiés ou non, émanant des établissements d'enseignement et de recherche français ou étrangers, des laboratoires publics ou privés. 


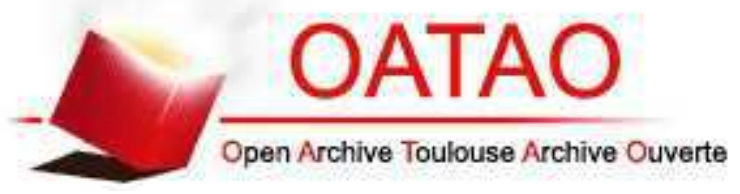

\section{Open Archive Toulouse Archive Ouverte (OATAO)}

OATAO is an open access repository that collects the work of Toulouse researchers and makes it freely available over the web where possible.

This is an author-deposited version published in: http://oatao.univ-toulouse.fr/ Eprints ID: 9939

To link to this article: DOI:10.1007/s10482-012-9859-z

http://dx.doi.org/10.1007/s10482-012-9859-z

\section{To cite this version:}

Meklat, Atika and Bouras, Noureddine and Zitouni, Abdelghani and Mathieu, Florence and Lebrihi, Ahmed and Schumann, Peter and Spröer, Cathrin and Klenk, Hans-Peter and Sabaou, Nasserdine Actinopolyspora saharensis sp. nov., a novel halophilic actinomycete isolated from a Saharan soil of Algeria. (2013) Antonie van Leeuwenhoek, vol. 103 ( ${ }^{\circ}$ 4). pp. 771-776. ISSN 0003-6072

Any correspondence concerning this service should be sent to the repository administrator: staff-oatao@ listes-diff.inp-toulouse.fr 


\title{
Actinopolyspora saharensis sp. nov., a novel halophilic actinomycete isolated from a Saharan soil of Algeria
}

\author{
Atika Meklat • Noureddine Bouras • Abdelghani Zitouni • Florence Mathieu • \\ Ahmed Lebrihi · Peter Schumann • Cathrin Spröer • Hans-Peter Klenk • \\ Nasserdine Sabaou
}

\begin{abstract}
A novel halophilic actinomycete, strain $\mathrm{H} 32^{\mathrm{T}}$, was isolated from a Saharan soil sample collected in El-Oued province, south Algeria. The isolate was characterized by means of polyphasic taxonomy. Optimal growth was determined to occur at $28-32{ }^{\circ} \mathrm{C}, \mathrm{pH}$
\end{abstract}

A. Meklat · N. Bouras · A. Zitouni $\cdot$ N. Sabaou $(\bowtie)$ Laboratoire de Biologie des Systèmes Microbiens (LBSM), Ecole Normale Supérieure de Kouba, Alger, Algeria

e-mail: sabaou@yahoo.fr

A. Meklat

Département de Biologie, Faculté des sciences Agronomiques, Vétérinaires et Biologiques,

Université Saâd Dahleb de Blida, Blida, Algeria

F. Mathieu · A. Lebrihi

Laboratoire de Génie Chimique, UMR 5503

(CNRS/INPT/UPS), INPT-ENSAT, Université de

Toulouse, 1 Avenue de l'Agrobiopôle, Auzeville

Tolosane, BP 32607, 31326 Castanet-Tolosan, France

\section{A. Lebrihi}

Université Moulay Ismail, Marjane 2, BP 298 Meknes,

Morocco

P. Schumann · C. Spröer · H.-P. Klenk

Leibniz Institute DSMZ, German Collection

of Microorganisms and Cell Cultures, Inhoffenstraße 7B,

38124 Braunschweig, Germany
6.0-7.0 and in the presence of $15-25 \%(\mathrm{w} / \mathrm{v}) \mathrm{NaCl}$. The strain was observed to produce abundant aerial mycelium, which formed long chains of rod-shaped spores at maturity, and fragmented substrate mycelium. The cell wall was determined to contain meso-diaminopimelic acid and the characteristic whole-cell sugars were arabinose and galactose. The predominant menaquinones were found to be MK-10 $\left(\mathrm{H}_{4}\right)$ and MK-9 $\left(\mathrm{H}_{4}\right)$. The predominant cellular fatty acids were determined to be anteiso $\mathrm{C}_{17: 0}$, iso- $\mathrm{C}_{15: 0}$ and iso- $\mathrm{C}_{16: 0}$. The diagnostic phospholipid detected was phosphatidylcholine. Phylogenetic analyses based on the 16S rRNA gene sequence showed that this strain formed a distinct phyletic line within the radiation of the genus Actinopolyspora. The $16 \mathrm{~S}$ rRNA gene sequence similarity indicated that strain $\mathrm{H} 32^{\mathrm{T}}$ was most closely related to 'Actinopolyspora algeriensis' DSM $45476^{\mathrm{T}}(98.8 \%)$ and Actinopolyspora halophila DSM $43834^{\mathrm{T}}(98.5 \%)$. Furthermore, the result of DNA-DNA hybridization between strain $\mathrm{H} 32^{\mathrm{T}}$ and the type strains 'A. algeriensis' DSM $45476^{\mathrm{T}}$, A. halophila DSM $43834^{\mathrm{T}}$ and Actinopolyspora mortivallis DSM $44261^{\mathrm{T}}$ demonstrated that this isolate represents a different genomic species in the genus Actinopolyspora. Moreover, the physiological and biochemical data allowed the differentiation of strain $\mathrm{H} 32^{\mathrm{T}}$ from its closest phylogenetic neighbours. Therefore, it is proposed that strain $\mathrm{H} 32^{\mathrm{T}}$ represents a novel species of the genus Actinopolyspora, for which the name Actinopolyspora saharensis sp. nov. is proposed. The type strain is $\mathrm{H} 32^{\mathrm{T}}$ (=DSM $45459^{\mathrm{T}}=\mathrm{CCUG}$ $62966^{\mathrm{T}}$ ). 
Keywords Actinopolyspora $\cdot$ A. saharensis sp.nov. · Halophilic actinomycete $\cdot$ Sahara .

Polyphasic taxonomy

\section{Introduction}

The genus Actinopolyspora was proposed by Gochnauer et al. (1975) and its description has been emended recently by Tang et al. (2011). It currently encompasses the species Actinopolyspora halophila (Gochnauer et al. 1975), Actinopolyspora mortivallis (Yoshida et al. 1991), Actinopolyspora xinjiangensis (Guan et al. 2010), Actinopolyspora egyptensis (Hozzein and Goodfellow 2011), Actinopolyspora alba and Actinopolyspora erythraea (Tang et al. 2011) and Actinopolyspora algeriensis (Meklat et al. 2012). The two species 'A. egyptensis' (Hozzein and Goodfellow 2011) and 'A. algeriensis' (Meklat et al. 2012) were described recently but these names have not yet been validated. The genus is characterized by a cell wall of type IVA (meso-diaminopimelic acid, arabinose and galactose), a type PIII phospholipid pattern (phosphatidylcholine), the presence of MK-9 $\left(\mathrm{H}_{4}\right)$ and MK-10 $\left(\mathrm{H}_{4}\right)$ or MK-9 $\left(\mathrm{H}_{4}\right)$ and MK-9 $\left(\mathrm{H}_{2}\right)$ as the predominant menaquinones, the presence of iso- $\mathrm{C}_{16: 0}$ and anteiso- $\mathrm{C}_{17: 0}$ as the major fatty acids and the absence of mycolic acids (Gochnauer et al. 1989; Tang et al. 2011). The $\mathrm{G}+\mathrm{C}$ contents of the genomic DNA are 64-69 mol\%.

During a study on halophilic actinomycetes from Saharan soils in El-Oued province (south Algeria), strain $\mathrm{H} 32^{\mathrm{T}}$ was isolated and purified. The present study was carried out to determine the taxonomic status of this strain by using a polyphasic approach. Based on phenotypic and genotypic evidence, it is proposed that the strain $\mathrm{H} 32^{\mathrm{T}}$ represents a novel species of the genus Actinopolyspora, for which the name Actinopolyspora saharensis sp. nov. is proposed.

\section{Materials and methods}

Isolation and maintenance of isolate

During an investigation of actinomycete diversity in Saharan soils (Meklat et al. 2011), strain $\mathrm{H} 32^{\mathrm{T}}$ was isolated from a soil sample collected from El-Oued province $\left(33^{\circ} 19^{\prime} 59^{\prime \prime} \mathrm{N}, 6^{\circ} 52^{\prime} 59^{\prime \prime} \mathrm{E}\right)$, south Algeria. Isolation was carried out by a dilution-plate method using humic acid-vitamin agar medium (Hayakawa and Nonomura 1987) supplemented with actidione $\left(50 \mu \mathrm{g} \mathrm{ml}^{-1}\right)$ and $20 \%(\mathrm{w} / \mathrm{v}) \mathrm{NaCl}$. After 4 weeks of incubation at $30{ }^{\circ} \mathrm{C}$, the isolate, which formed a white colony, was transferred and purified on complex medium (CM) agar (Chun et al. 2000) supplemented with $20 \%(\mathrm{w} / \mathrm{v}) \mathrm{NaCl}$. The purified strain was maintained on $\mathrm{CM}$ agar slants at $4{ }^{\circ} \mathrm{C}$ and as $20 \%$ (v/v) glycerol suspensions at $-20^{\circ} \mathrm{C}$. Strain $\mathrm{H} 32^{\mathrm{T}}$ was deposited in the German Collection of Microorganisms and Cell Cultures (DSMZ) as strain DSM $45459^{\mathrm{T}}$, and in the Culture Collection, University of Göteborg, Sweden (CCUG) as strain CCUG $62966^{\mathrm{T}}$.

Phenotypic characterization

Characterization of strain $\mathrm{H} 32^{\mathrm{T}}$ was determined after growth at $30{ }^{\circ} \mathrm{C}$ for 3 weeks using the media of the International Streptomyces Project, ISP 2 and ISP 4 (Shirling and Gottlieb 1966), and also CM agar (Chun et al. 2000) and nutrient agar (Waksman 1961). The colours of the substrate and aerial mycelia and any soluble pigments produced were determined by comparison with ISCC-NBS colour charts (Kelly and Judd 1976). The morphological characteristics of strain $\mathrm{H} 32^{\mathrm{T}}$, including spore-chain morphology, spore size and surface ornamentation, were assessed by light microscopy (B1, Motic) and scanning electron microscopy (Hitachi S450). Several physiological tests were used to characterize actinomycete strain. Growth at different temperatures $(10,15,25,28,30$, $32,35,40$ and $\left.45^{\circ} \mathrm{C}\right)$, various $\mathrm{pH}$ values $(5.0,6.0,7.0$ 8.0 and 9.0 using the buffer system described by $\mathrm{Xu}$ et al. 2005) and $\mathrm{NaCl}$ concentrations $(0,7,10,15,20$, $25,28,30,32$ and $35 \%$; w/v) were determined by using nutrient agar medium, with the cultures incubated for 21 days at $30{ }^{\circ} \mathrm{C}$. Utilization of carbohydrates and decarboxylation of organic acids were evaluated using the method of Gordon et al. (1974). Degradation of different other organic compounds was studied as described by Goodfellow (1971). Lysozyme sensitivity and production of nitrate reductase were determined according to the methods of Gordon and Barnett (1977) and Marchal et al. (1987), respectively.

\section{Chemotaxonomy}

For the chemotaxonomic analyses, strain $\mathrm{H} 32^{\mathrm{T}}$ was grown in complex broth medium containing $15 \%$ (w/v) 
$\mathrm{NaCl}$ at $30^{\circ} \mathrm{C}$ for 10 days on a rotary shaker (250 rpm). Biomass was harvested by centrifugation at 3,500 rpm and washed several times with distilled water. Analysis of diaminopimelic acid and whole-cell sugars was carried out using the methods of Becker et al. (1964) and Lechevalier and Lechevalier (1970). Phospholipids were analyzed according to the procedures developed by Minnikin et al. (1977). Menaquinones were isolated according to Minnikin and O’Donnell (1984) and were analyzed by HPLC (Kroppenstedt 1982, 1985). The cellular fatty acid composition was studied as described by Sasser (1990) using the microbial identification system.

Phylogenetic analyses

The genomic DNA of $\mathrm{H} 32^{\mathrm{T}}$ was extracted according to the method of Liu et al. (2000). PCR amplification of the 16S rRNA gene and sequencing of the purified PCR products were carried out as described by Rainey et al. (1996). The sequences obtained were compared with sequences present in the public sequence databases as well as with the EzTaxon-e server (http://eztaxon-e.ezbiocloud.net/; Kim et al. 2012), a web-based tool for the identification of prokaryotes based on 16S rRNA gene sequences from type strains. The 16S rRNA sequence of strain $\mathrm{H} 32^{\mathrm{T}}$ was aligned using the CLUSTAL W (Larkin et al. 2007) against corresponding nucleotide sequences retrieved from GenBank. Phylogenetic trees were constructed by using the neighbour-joining (Saitou and Nei 1987) with Jukes and Cantor (1969) model, maximumlikelihood (Felsenstein 1981) with Kimura 2-parameter (Kimura 1980) model and maximum-parsimony (Fitch 1977) methods. The topology of the tree was evaluated by bootstrap analysis based on 1,000 replicates (Felsenstein 1985). DNA-DNA hybridization was carried out as described by De Ley et al. (1970) incorporating the modifications described by Huss et al. (1983). The experiments were done as duplicates in $2 \times \mathrm{SSC}$ in the presence of $10 \%$ formamide at $71{ }^{\circ} \mathrm{C}$.

\section{Results and discussion}

Strain $\mathrm{H} 32^{\mathrm{T}}$ was observed to grow well on CM agar, NA and ISP 2 media, with a well-developed whiteyellow aerial mycelium that fragmented into rod- shaped spores. The spores were determined to have a smooth surface (Fig. 1) and be non-motile. Growth was found to be weak on ISP 4 medium, with the aerial mycelium poorly developed. The substrate mycelium showed light yellow or pale yellow colouration and exhibited a good fragmentation. A light yellowish diffusible pigment was found to be produced on CM agar medium after incubation for three weeks.

Strain $\mathrm{H} 32^{\mathrm{T}}$ was determined to contain mesodiaminopimelic acid (but not glycine) in its cell wall. Whole-cell hydrolysates were found to contain arabinose and galactose (in addition to ribose), which is typical of cell-wall type IV and whole-cell sugar pattern type A (Lechevalier and Lechevalier 1970). The diagnostic phospholipid detected was phosphatidylcholine, corresponding to phospholipid type PIII (Lechevalier et al. 1977). Diphosphatidylglycerol, phosphatidylglycerol, phosphatidylinositol, two unknown phospholipids and three unknown glycolipids were also detected (Supplementary Fig. S1a, b and c). The predominant menaquinones were determined to be MK-10 $\left(\mathrm{H}_{4}\right)(29.4 \%)$ and MK-9 $\left(\mathrm{H}_{4}\right)(22.4 \%)$ and minor amounts of MK-10 $\left(\mathrm{H}_{2}\right)(9.4 \%), \mathrm{MK}-11$

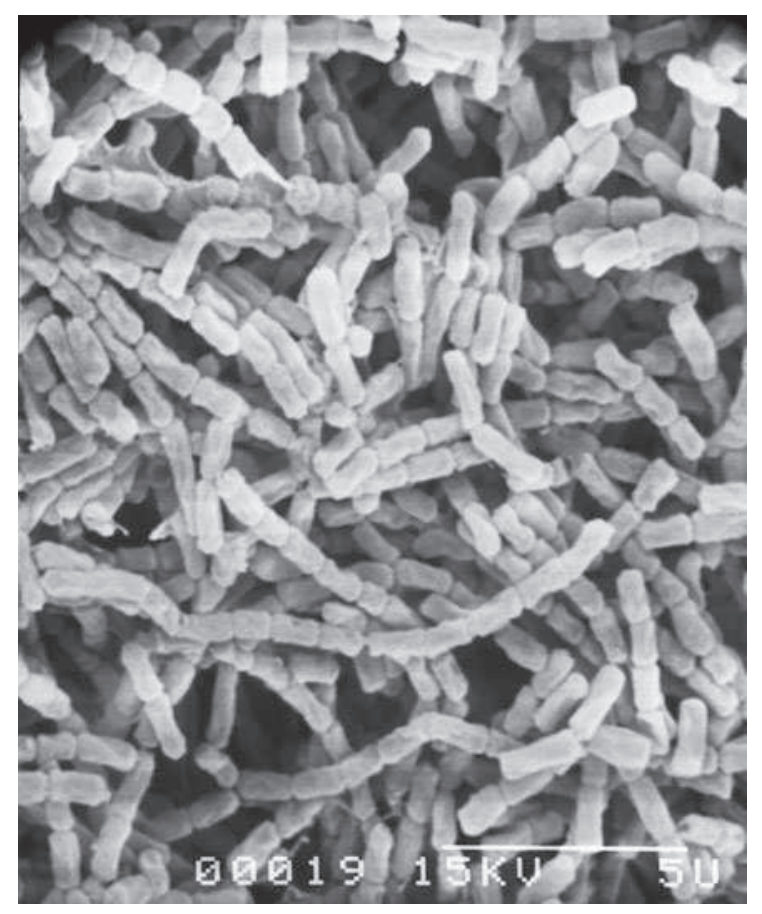

Fig. 1 Scanning electron micrograph of strain $\mathrm{H} 32^{\mathrm{T}}$ grown on ISP 2 medium containing $15 \%(\mathrm{w} / \mathrm{v}) \mathrm{NaCl}$ for 28 days at $30{ }^{\circ} \mathrm{C}$. Bar $5 \mu \mathrm{m}$ 
$\left(\mathrm{H}_{4}\right)(8.3 \%)$, MK-8 $\left(\mathrm{H}_{4}\right)(5.9 \%)$, MK-9 $\left(\mathrm{H}_{2}\right)(5.3 \%)$, MK-11 $\left(\mathrm{H}_{2}\right)(3.0 \%)$ and MK-10 $\left(\mathrm{H}_{6}\right)(1.9 \%)$ were also detected. The fatty acids profile was composed as follows: anteiso- $\mathrm{C}_{17: 0},(30.8 \%)$, iso- $\mathrm{C}_{15: 0}(20.4 \%)$, iso- $\mathrm{C}_{16: 0}(15.6 \%)$, iso- $\mathrm{C}_{17: 0}(9.3 \%)$ and anteiso- $\mathrm{C}_{15: 0}$ $(9.1 \%)$. The morphological and chemical characteristics described above clearly support the placement of strain $\mathrm{H} 32^{\mathrm{T}}$ within the genus Actinopolyspora.

Good growth was found to occur at $28-32{ }^{\circ} \mathrm{C}, \mathrm{pH}$ $6.0-7.0$ and in the presence of $15-25 \%$ of $\mathrm{NaCl}$. The

Table 1 Differential characteristics of strain $\mathrm{H} 32^{\mathrm{T}}$ (Actinopolyspora saharensis sp. nov.) compared with its closest relative recognized species of the genus Actinopolyspora

\begin{tabular}{ll}
\hline Characteristics & $\begin{array}{l}\text { Type } \\
\text { strains }\end{array}$ \\
$\frac{1}{1} 2$ & 3
\end{tabular}

\begin{tabular}{|c|c|c|}
\hline \multicolumn{3}{|l|}{ Utilization of } \\
\hline D-cellobiose & + & - \\
\hline Erythritol & - & - \\
\hline D-galactose & + & - \\
\hline D-glucose & + & $-*$ \\
\hline Inositol & - & + \\
\hline D-lactose & + & - \\
\hline D-maltose & + & - \\
\hline D-mannitol & - & + \\
\hline D-mannose & + & $-*$ \\
\hline Raffinose & - & - \\
\hline Salicin & - & $+*$ \\
\hline Sucrose & + & - \\
\hline D-xylose & + & - \\
\hline \multicolumn{3}{|l|}{ Decomposition of } \\
\hline Casein & - & + \\
\hline Hypoxanthine & + & + \\
\hline Starch & + & - \\
\hline Xanthine & + & - \\
\hline Production of nitrate reductase & + & - \\
\hline Resistance to lysozyme (0.005 \% w/v) & + & - \\
\hline Growth in the presence of 7 and $32 \%$ of $\mathrm{NaCl}$ & - & - \\
\hline
\end{tabular}

The phenotypic properties of strains A. saharensis $\mathrm{H} 32^{\mathrm{T}}$, A. halophila DSM $43834^{\mathrm{T}}$ and 'A. algeriensis' DSM $45476^{\mathrm{T}}$ grown under the same conditions were determined in the present study. Strains: 1 A. saharensis $\mathrm{H} 32^{\mathrm{T}}, 2$ A. halophila DSM $43834^{\mathrm{T}}, 3$ 'A. algeriensis' DSM $45476^{\mathrm{T}}$, + positive, - negative

* Variable or doubtful results were obtained by Yoshida et al. (1991), Guan et al. (2010), Hozzein and Goodfellow (2011) and Tang et al. (2011) organism is resistant to kanamycin $\left(5 \mu \mathrm{g} \mathrm{ml} l^{-1}\right)$, erythromycin $\left(10 \mu \mathrm{g} \mathrm{ml}^{-1}\right)$, streptomycin $\left(10 \mu \mathrm{g} \mathrm{ml}^{-1}\right)$, penicillin $\left(25 \mu \mathrm{g} \mathrm{ml}^{-1}\right)$ and lysozyme $(0.005 \% \mathrm{w} / \mathrm{v})$, but sensitive to chloramphenicol $\left(25 \mu \mathrm{g} \mathrm{ml}{ }^{-1}\right)$. Detailed results of the physiological and biochemical analyses are given in Table 1 and in the species description. It is evident from Table 1 that there are several phenotypic characteristics that clearly separate strain $\mathrm{H} 32^{\mathrm{T}}$ from the nearest recognized species 'A. algeriensis' and 'A. halophila'.

Phylogenetic analysis of an almost complete $16 \mathrm{~S}$ rRNA gene sequence (GenBank accession number HQ918198) showed that strain $\mathrm{H} 32^{\mathrm{T}}$ was related to members of the genus Actinopolyspora and exhibited highest 16S rRNA gene sequence similarity to 'A. algeriensis' (98.8\%) and A. halophila (98.5\%), whereas the sequence similarities between strain $\mathrm{H} 32^{\mathrm{T}}$ and other members of the genus Actinopolyspora ranged from 96.5 to $97.2 \%$. The phylogenetic relationship between strain $\mathrm{H} 32^{\mathrm{T}}$ and the other Actinopolyspora species is seen in the neighbour-joining dendrogram (Fig. 2). Maximum parsimony and maximum-likelihood calculation resulted in a similar tree topology (Supplementary Fig. S2). DNA-DNA relatedness between strain $\mathrm{H} 32^{\mathrm{T}}$ and the type strains 'A. algeriensis' DSM $45476^{\mathrm{T}}$, A. halophila DSM $43834^{\mathrm{T}}$ and A. mortivallis DSM $44261^{\mathrm{T}}$ were respectively mean values of $30.5 \%$ (30.4 and $30.6 \%$ ), $55.1 \%(54.3$ and $56.0 \%)$ and $31.5 \%$ (28.1 and $34.1 \%)$. These hybridization values were significantly less than $70 \%$, the threshold value for the delineation of genomic species (Wayne et al. 1987). Thus, on the basis of polyphasic taxonomic evidence, it is suggested that strain $\mathrm{H} 32^{\mathrm{T}}$ represents a novel species of the genus Actinopolyspora, for which the name Actinopolyspora saharensis sp. nov. is proposed.

Description of A. saharensis sp. nov.

Actinopolyspora saharensis (sa.ha.ren'sis, N.L. fem. adj. saharensis pertaining to Sahara, where the type strain was isolated).

Halophilic filamentous actinomycete that forms well-fragmented substrate mycelium. Aerial mycelium is well-developed white-yellow colour on ISP 2, nutrient agar and CM agar media, and is irregularly branched and forms straight to flexuous chains of 10-30 rod-shaped spores. A light yellowish soluble pigment is produced on CM agar medium. 


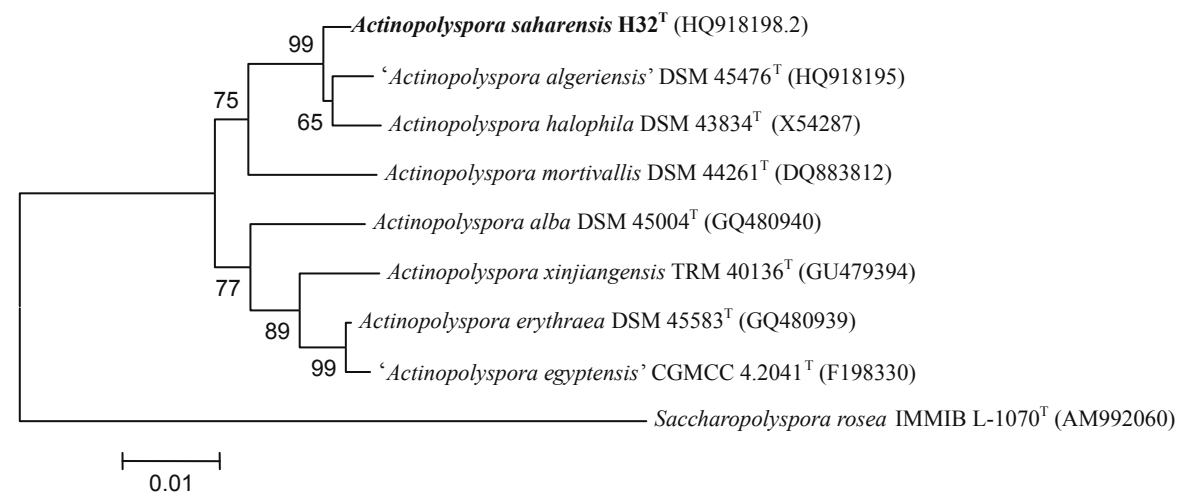

Fig. 2 Phylogenetic tree for species of the genus Actinopolyspora calculated from almost complete 16S rRNA gene sequences using Jukes and Cantor (1969) evolutionary distance methods and the neighbour-joining method of Saitou and Nei (1987). This illustrates the taxonomic position of strain H32

Temperature and $\mathrm{pH}$ ranges for growth are $20-35{ }^{\circ} \mathrm{C}$ and $\mathrm{pH} 5.0-8.0$, with optima at $28-32{ }^{\circ} \mathrm{C}$ and $\mathrm{pH}$ 6.0-7.0. The $\mathrm{NaCl}$ concentration range for growth is 10-30 \%, with optimal growth occurring at 15-20\%. Utilizes adonitol, arabinose, cellobiose, fructose, galactose, glucose, glycerol, lactose, maltose, mannose, rhamnose, sucrose, trehalose and xylose but not erythritol, inositol, mannitol, melezitose, melibiose, raffinose, ribose, salicin and sorbitol. Positive for adenine, gelatin, hypoxanthine, starch, Tween 80 and xanthine hydrolysis but negative for casein, guanine, testosterone and tyrosine hydrolysis. Citrate is decarboxylated but not acetate, benzoate, butyrate, oxalate, propionate, pyruvate, succinate and tartrate. L-proline is used as a source of nitrogen but not L-alanine and Lserine. Nitrate reductase is produced. Whole-cell hydrolysates contain meso-diaminopimelic acid, arabinose and galactose. The diagnostic phospholipid is phosphatidylcholine (type PIII sensu Lechevalier et al. 1977). The predominant menaquinones are MK-10 $\left(\mathrm{H}_{4}\right)$ and MK-9 $\left(\mathrm{H}_{4}\right)$. The major fatty acids are anteiso$\mathrm{C}_{17: 0}$, iso- $\mathrm{C}_{15: 0}$, iso- $\mathrm{C}_{16: 0}$, iso- $\mathrm{C}_{17: 0}$ and anteiso- $\mathrm{C}_{15: 0}$.

The type strain, $\mathrm{H} 32^{\mathrm{T}}\left(=\mathrm{DSM} 45459^{\mathrm{T}}=\mathrm{CCUG}\right.$ $62966^{\mathrm{T}}$ ), was isolated from a Saharan soil sample collected from El-Oued province (south Algeria). The GenBank accession number for the 16S rRNA gene sequence of strain H32 is HQ918198.

Acknowledgments The authors are grateful to Khaled Kherraz for soil sampling from El-Oued province, Gabriele Pötter (DSMZ) for growing A. saharensis cultures and for assistance relative to the other species of the genus. Numbers at the nodes are bootstrap values, expressed as a percentage of 1,000 resamplings (only values $>50 \%$ are shown). Bar 0.01 nucleotide substitution per site

with chemotaxonomical analyses and Bettina Sträubler for assistance with DNA-DNA hybridizations.

\section{References}

Becker B, Lechevalier MP, Gordon RE, Lechevalier HA (1964) Rapid differentiation between Nocardia and Streptomyces by paper chromatography of whole-cell hydrolysates. J Appl Microbiol 12:421-423

Chun J, Bae KS, Moon EY, Jung SO, Lee HK, kim SJ (2000) Nocardiopsis kunsanensis sp. nov., a moderately halophilic actinomycete isolated from a saltern. Int J Syst Evol Microbiol 50:1909-1913

De Ley J, Cattoir H, Reynaerts A (1970) The quantitative measurement of DNA hybridization from renaturation rates. Eur J Biochem 12:133-142

Felsenstein J (1981) Evolutionary trees from DNA sequences: a maximum likelihood approach. J Mol Evol 17:368-376

Felsenstein J (1985) Confidence limits on phylogenies: an approach using the bootstrap. Evolution 39:783-791

Fitch WM (1977) On the problem of discovering the most parsimonious tree. Am Nat 111:223-257

Gochnauer MB, Leppard GG, Komaratat P, Kates M, Novitsky T, Kushner DJ (1975) Isolation and characterization of Actinopolyspora halophila, gen. sp. nov., an extremely halophilic actinomycete. Can J Microbiol 2:1500-1511

Gochnauer MB, Johnson KG, Kushner DJ (1989) Genus Actinopolyspora. In: Williams ST, Sharpe ME, Holt JG (eds) Bergey's manual of systematic bacteriology, vol 4. Williams and Wilkins, Baltimore, pp 2398-2401

Goodfellow M (1971) Numerical taxonomy of some nocardioform bacteria. J Gen Microbiol 69:33-90

Gordon RE, Barnett DA (1977) Resistance to rifampicin and lysozyme of strains of some species of Mycobacterium and Nocardia as a taxonomic tool. Int J Syst Bacteriol 27: 176-178 
Gordon RE, Barnett DA, Handerhan JE, Pang CHN (1974) Nocardia coeliaca, Nocardia autotrophica, and the nocardin strain. Int J Syst Bacteriol 24:54-63

Guan TW, Liu Y, Zhao K, Xia ZF, Zhang XP, Zhang LL (2010) Actinopolyspora xinjiangensis sp. nov., a novel extremely halophilic actinomycete isolated from a salt lake in Xinjiang, China. Antonie Leeuwenhoek 98:447-453

Hayakawa M, Nonomura H (1987) Humic acid-vitamin agar, a new medium for the selective isolation of soil actinomycetes. J Ferment Technol 65:501-509

Hozzein WN, Goodfellow M (2011) Actinopolyspora egyptensis sp. nov., a new halophilic actinomycete. Afr J Microbiol Res 5:100-105

Huss VAR, Festl H, Schleifer KH (1983) Studies on the spectrophotometric determination of DNA hybridization from renaturation rates. Syst Appl Microbiol 4:184-192

Jukes TH, Cantor CR (1969) Evolution of protein molecules. In: Munro HN (ed) Mammalian protein metabolism, vol 3. Academic Press, New York, pp 21-132

Kelly KL, Judd DB (1976) Color. Universal language and dictionary of names (National Bureau of Standards special publication 440). US Department of Commerce, Washington, DC

Kim OS, Cho YJ, Lee K, Yoon SH, Kim M, Na H, Park SC, Jeon YS, Lee JH, Yi H, Won S, Chun J (2012) Introducing EzTaxon-e: a prokaryotic 16S rRNA gene sequence database with phylotypes that represent uncultured species. Int J Syst Evol Microbiol 62:716-721

Kimura M (1980) A simple method for estimating evolutionary rates of base substitutions through comparative studies of nucleotide sequences. J Mol Evol 16:111-120

Kroppenstedt RM (1982) Separation of bacterial menaquinones by HPLC using reverse phase (RP18) and a silver loaded ion exchanger as stationary phases. J Liq Chromatogr 5:2359-2367

Kroppenstedt RM (1985) Fatty acid and menaquinone analysis of actinomycetes and related organisms. In: Goodfellow M, Minnikin DE (eds) Chemical methods in bacterial systematics. Academic Press, London, pp 173-179

Larkin MA, Blackshields G, Brown NP, Chenna R, McGettigan PA, McWilliam H, Valentin F, Wallace IM, Wilm A, Lopez R, Thompson JD, Gibson TJ, Higgins DG (2007) CLUSTALW and CLUSTALX version 2. Bioinformatics 23:2947-2948

Lechevalier MP, Lechevalier HA (1970) Chemical composition as a criterion in the classification of aerobic actinomycetes. Int J Syst Bacteriol 34:435-444

Lechevalier MP, de Bièvre C, Lechevalier HA (1977) Chemotaxonomy of aerobic actinomycetes: phospholipid composition. Biochem Syst Ecol 5:249-260

Liu D, Coloe S, Baird R, Pedersen J (2000) Rapid mini-preparation of fungal DNA for PCR. J Clin Microbiol 38:471

Marchal N, Bourdon JL, Richard CL (1987) Les milieux de culture pour l'isolement et l'identification biochimique des bactéries. Doin Press, Paris
Meklat A, Zitouni A, Mathieu F, Lebrihi A, Sabaou N (2011) Halophilic actinomycetes in Saharan soils of Algeria: isolation, taxonomy and antagonistic properties. Appl Environ Microbiol 77:6710-6714

Meklat A, Bouras N, Zitouni A, Mathieu F, Lebrihi A, Schumann P, Spröer C, Klenk HP, Sabaou N (2012) Actinopolyspora algeriensis sp. nov., a novel halophilic actinomycete isolated from a Saharan soil. Extremophiles 16:771-776

Minnikin DE, O’Donnell AG (1984) Actinomycete envelope lipid and peptidoglycan composition. In: Goodfellow M, Mordarski M, Williams ST (eds) The biology of the actinomycetes. Academic Press, London, pp 337-388

Minnikin DE, Patel PV, Alshamaony L, Goodfellow M (1977) Polar lipid composition in the classification of Nocardia and related bacteria. Int J Syst Bacteriol 27:104-117

Rainey FA, Ward-Rainey N, Kroppenstedt RM, Stackebrandt E (1996) The genus Nocardiopsis represents a phylogenetically coherent taxon and a distinct actinomycete lineage: proposal of Nocardiopsaceae fam. nov. Int J Syst Bacteriol 46:1088-1092

Saitou N, Nei M (1987) The neighbor-joining method: a new method for reconstructing phylogenetic trees. Mol Biol Evol 4:406-425

Sasser M (1990) Identification of bacteria by gas chromatography of cellular fatty acids. Technical note 101 . Microbial ID, Newark

Shirling EB, Gottlieb D (1966) Methods for characterization of Streptomyces species. Int J Syst Bacteriol 16:313-340

Tang SK, Wang Y, Klenk HP, Shi R, Lou K, Zhang YJ, Chen C, Ruan JS, Li WJ (2011) Actinopolyspora alba sp. nov. and Actinopolyspora erythraea sp. nov., isolated from a salt field, and reclassification of Actinopolyspora iraqiensis Ruan et al. 1994 as a heterotypic synonym of Saccharomonospora halophila. Int J Syst Evol Microbiol 61:1693-1698

Waksman SA (1961) Classification, identification, and descriptions of genera and species. In: The actinomycetes, vol 2. Williams \& Wilkins, Baltimore, pp 331-332

Wayne LG, Brenner DJ, Colwell RR, Grimont PAD, Kandler O, Krichevsky MI, Moore LH, Moore WEC, Murray RGE, Stackebrandt E, Starr MP, Trüper HG (1987) International committee on systematic bacteriology. Report of the ad hoc committee on the reconciliation of approaches to bacterial systematic. Int J Syst Bacteriol 37:463-464

Xu P, Li WJ, Tang SK, Zhang YQ, Chen GZ, Chen HH, Xu LH, Jiang CL (2005) Naxibacter alkalitolerans gen. nov., sp. nov., a novel member of the family 'Oxalobacteraceae' isolated from China. Int J Syst Evol Microbiol 55: $1149-1153$

Yoshida M, Matsubara K, Kudo T, Horikoshi K (1991) Actinopolyspora mortivallis sp. nov., a moderately halophilic actinomycete. Int J Syst Bacteriol 41:15-20 